\title{
Frozen Fish Markets and Marketing Problems in Ibadan, Nigeria
}

\author{
Teslim Bada \\ Department of Economics, University of Portsmouth, UK \\ E-mail: tesbom@yahoo.com \\ M.A.Y. Rahji (Corresponding author) \\ Department of Agricultural Economics, University of Ibadan, Nigeria \\ E-mail: mayrahji@yahoo.com
}

\begin{abstract}
This paper examined the performance of the frozen fish markets in Ibadan, Nigeria in terms of price transmission, market margins, marketing costs, and the magnitude of changes in these variables. The study revealed that the average retail price for Mackerel is higher than that of Stockfish while that of Stockfish is greater than that of Sadinela. The same pattern is observed for the wholesale prices, marketing costs and net margins. All the measures used to assess the problems gave the same rank ordering. Power supply is first. This is followed by storage, spoilage, transport cost, finance and lastly market levies. A high level of refrigeration is required. Hence unstable power supply could result in spoilage or deterioration in the quality and economic value of fish. There is the need for improvement in the fish market environment in terms of the provision of infrastructures such as electricity and storage facilities.
\end{abstract}

Keywords: Frozen fish, Marketing margins, Marketing problems, Ibadan, Nigeria

\section{Introduction}

Nigeria is endowed with many large rivers, man-made lakes, creeks and about 200 nautical miles of marine water under the Exclusive Economic Zone (EEZ). The country has seven maritime states. These are Lagos, Ondo, Delta, Rivers, Ogun and Akwa - Ibom states. The Fishery industry has, however, not attained the desired level of self sufficiency in local fish production (Idachaba, 1991).

In Nigeria, total domestic fish production is far less than the total domestic demand. According to Zango-Daura (2000), the country requires 750,000 tonnes of fish while domestic production amounted to 350,000 tonnes. Fish importation makes up the balance of 400,000 tonnes. Importation is thus often used to bridge the fish supply demand gap (Rahji et al; 2001). Nigerian's importation of fish is worth about N12 billion annually (Zango Daura, 2000).

According to Zango-Daura (2000), Nigeria requires about 1.5 million tonnes of fish annually. This is what is needed to meet FAO's recommended minimum fish consumption rate of 12.5 Kilograms per head yearly to satisfy basic protein needs. For now, the unsatisfied demand will continue to be met through importation unless policy actions are geared towards improving domestic productions through aquaculture.

\subsection{Importance of fish marketing and Distribution}

The focus of this study is on the negative effect of fish imports on the economy of Nigeria. These effects are in terms of the foreign exchange components which constitute a drain on the foreign reserves. There is also a lack of production substitution for imported fish species. The major species imported are Sadinella eba (Sardines) Mackerel spp (Mackerel) and Hake (Stock Fish). The markets for fish and marketing of frozen fish are thus of policy relevance.

This is in terms of the price dynamics, marketing costs and the marketing functions inherent in the distribution of fish and in relation to how effective or efficient the marketing system is. This is because price relations among spatially dispersed markets are important in many contexts (Silvapulle and Jayasuriya, 1994). Spatial price behavior is an important indicator of overall market performance (Goodwin and Schroeder, 1991) in terms of marketing efficiency. An efficient marketing system stimulates production. Producers are likely produce more if they are able to sell at reasonable prices. Similarly, an efficient marketing system stimulates consumption as 
consumers are likely to buy more, if they are able to purchase their requirements in the right form, place, time, and at a minimum cost for a maximum satisfaction(Adekanye, 1988).

\subsection{Problem Statement}

It is known that there are quite a number of approaches for carrying out market analysis Some of these have been found relevant to the subject of frozen fish market analysis and problems inherent in frozen fish markets. Local fish are limited in supply in Nigeria hence the demand for fish is higher than supply in Nigeria The demand - supply gap problem still persists. This is the more reason why the marketing of frozen fish with its foreign exchange implications should be as efficiently carried out as possible. So that this source of protein will not be out of the reach of the poor and vulnerable households and groups.

The problem therefore relates to the application of the functional market analysis to the frozen fish markets in Ibadan. This approach is particularly useful in evaluating marketing costs and it allows for a comparison of such costs for various commodities. Such studies are far and in between in the context of frozen fish marketing in Nigeria. Using this approach results in breaking down the complex marketing task involved in frozen marketing into its component functions. This is greatly expected to aid in the efforts to improve the performance of the marketing system. More so, marketing efficiency describes the movement of goods from the producers to the consumers at the lowest marketing cost consistent with the provision of the services that the consumers desire and able to afford. According to Adegeye and Dittoh (1985), marketing margin is one of the indicators usually identified with marketing efficiency. Adekanye (1988) defined marketing margins as the difference between what the producer gets and what the final retailer obtains from the ultimate consumer. This is usually expressed as a percentage of the consumer price.

Marketing inefficiency over a geographical area is attributed to high cost of providing marketing services (Adekanye, 1988). Low margins are regarded as a proof that the marketing system is not exploitative. If the margin is high the probability is high that the marketing cost is high and so is against the interest of the consumer's quest for minimum cost for maximum satisfaction. Therefore, there is the need for an efficient frozen fish marketing system in order to establish an effective linkage between suppliers and consumers of frozen fish.

The problem focus of this study is therefore to examine the marketing margins a proxy for marketing cost for frozen fish as basis for determining the efficiency or inefficiency of the marketing system for fish.

The performance of a market is reflected in the level of efficiency of its system. The case for frozen fish marketing system therefore comes as being of research relevance. This calls for an assessment of the performance and efficiency of the frozen fish markets in Nigeria in general and Ibadan in particular in this case.

\subsection{Objectives of the Study}

The overall objective is to assess the marketing of frozen fish in Ibadan, with a view to identifying the factors militating against efficient frozen fish marketing. This paper attempts to examine the performance of the frozen fish markets in Ibadan, Nigeria. As according to Jayaraj (1992), price transmission and market margin or marketing costs are measures of performance. It also tried to examine the magnitude of changes in market margin among three different frozen fish markets, which according to Schroeder and Godwin (1991), Plaskass and Harris - White (1993), and Dercon, (1995), should reflect changes in the supply and demand for marketing services in a competitive market. The specific objectives include to:

- identify the distribution channels and the market agents involved in frozen fish markets

- estimate the market margins for frozen fish in the different markets.

- assess the problems of frozen fish marketing in the markets.

- make policy recommendations based on the findings of this study.

\section{Methodology}

Area of Study: The Frozen Fish Markets

The frozen fish market as conceptualized in this study represents market places and the diffuse interactions of buyers and sellers, producers and consumers whose activities determine the prices of commodities. The concept includes the following appreciable environments the physical environments such as roads, drainage, transport, distance between market agents (producers, consumer and marketers), government and institutional environment, cultural environment, economic and market environment.

Bodija, Oke - Ado and Beere Frozen Fish Markets. 
The focus of this study is on the three markets identified above in Ibadan. These markets are indicative of an active urban area of marketing activities. The locations of the markets make for their easy differentiation on income level basis. Bodija market is located within a high income area while Oke-Ado is within a medium income area. Beere market falls within the low income area.

The choice of the markets was based on their advantages of size and location. Ibadan is of strategic marketing importance as it is a link between the North and other Southwestern locations. Ibadan is the third largest city in Nigeria by population (after Lagos and Kano), and the largest in geographical area. Its population is about 2.6 million according to the 2006 Census. It is made up of 11 (eleven) Local Government Areas (LGAs). The population of central Ibadan, made up of 5 LGAS is about 1.34 million by the Census reports of 2006. Ibadan covers an area of $128 \mathrm{~km}^{2}$. The importance of Ibadan is enhanced by the presence of the University of Ibadan and University Teaching Hospital (UCH)

\subsection{Method of Data Collection}

A purposive and random sampling of the relevant agents involved in the marketing of frozen fish and needed for this study was carried out. Fifteen (15) wholesalers were identified, and purposively sampled. This is because wholesalers are fewer in number as this level of marketing requires a lot of money for the operators to be effective. Ninety (90) final retailers were randomly selected because they are many in the markets studied. Information on prices of fish, costs incurred in the marketing of frozen fish and other relevant parameters were collected through structured questionnaires.

The breakdown is that 5 wholesalers were purposely sampled in each market, 30 final retailers were randomly selected from the list of retailers obtained from the Market Association in each market.

\subsection{Methods of Data Analysis}

(i) (a) Descriptive statistics which involves the use of means, averages, percentages, and frequency distributions. This becomes handy in the calculation of the market margins.

(b) Market Margin Analysis.

Market margin $=$ Retail price - wholesale price.

Net margin $=$ Market margin - Marketing costs

(ii) Weighted mean Analysis. In this, and for each problem identified, the product of the Likert Scale values of 1 to 5 , and the number of times a preference is recorded for it are summed up to obtain the weighted scores. The weighted scores are then divided by the sample size of the respondents to obtain the weighted means. These are used to rank the problems in terms of the severity.

(iii) Paired Comparison Method. This is used to measure the individual preference orderings of items presented to them as discrete or binary choice (Brown and Peterson, 2009). The summaries of the method are found in Guilford (1954), Torgerson (1958) and Nunnally (1976) and the statistical perspective is found in Bock and Jones (1968) and David (1988).

A set of items is judged by presenting all possible pairs of the items to each respondent. He then chooses for each pair the item that better satisfies the specified choice criterion. With a number of items $(\eta)$, there are $\eta$ $(\eta-1) / 2$ pairs in total. Each pair results in a binary choice. The choices allow the calculation of a set of scale values. For each respondent, the full set of choices yields a preference score for each item. This is the number of times the respondent preferred the item to the other items in the set.

Preference scores, the simplest form of scale values, are easily calculated by creating a $\eta$ by $\eta$ matrix and entering a 1 (one) in each cell where the column item is preferred to the row item or a 0 (zero) otherwise for the row item. Column scores, for this binary scoring, give the preference scores.

The Paired Comparison Table is made up of the column summed preference scores and the values of the total choices of the respondents. The total choice values are used to rank the problems so as to determine their importance.

(iv) Mean Proportion Method. The total choices are also used to calculate the Mean Proportion values (MPs), the Z- scores and the Ratio scales in that order.

(a)

$$
\mathrm{MP}=\frac{\mathrm{C}+0.5 \mathrm{~N}}{\eta \mathrm{N}}
$$


Where,

$\mathrm{C}=$ total choices for each problem from the Paired Comparison Table.

$\eta=$ number of items being compared in pairs.

$\mathrm{N}=$ number of respondents or the sample size of the respondents.

The magnitudes of the MPs are ranked in descending order to determine the level of severity of the problems. The larger the values of the MPs, the higher the severity of the problem.

(b) Z-scores. The MPs are then converted to Z-scores using the area in the tail of the normal distribution curve. If MP $>0.5$ say 0.775 , the formula to be used is $(1-\mathrm{MP})$ e.g. $(1-.0 .775=0.225)$. Using 0.225 in the normal curve table, the Z-score is obtained as 0.76 .

If $M P<0.5$, the actual value of MP is used but the $Z$ value is negative.

In this case, the lowest negative score indicates the lowest rating while the highest positive score shows the highest rating for the problem.

(c) The Ratio Scale. To develop the ratio scale, the smallest Z-score is converted to 0 (zero).

The absolute value of the smallest $\mathrm{Z}$-score is then added to the other z-scores to obtain the ratio scales. The greater the value of the ratio scale, the greater the importance of the problem and the lower its value is the smallest is the severity of the problem.

These three measures are used to rank the problems in order to determine their importance or order of severity.

\section{Results and Discussion}

In Nigeria, frozen fish are usually sourced from industrial fisheries. The firms in this sector have a charter agreement by which the Nigeria-based firms pay their foreign partners. In return, the foreign firms are allowed to fish for a period of time and deliver a specified quantity and types of fish. The Nigerian firms take delivery of the fish stock in frozen form.

In Nigeria therefore, the distribution of frozen fish has created a complex system of long distance trade. It therefore involves importers who are foreigners. These importers contract fish merchants or companies in Europe for the supply of fish because they have enough capital and are able to form a cartel. (Ladipo, 1988).

The first level in the distribution chain of frozen fish is that of the local wholesalers who own cold stores in coastal towns which are major landing points. The initial capital outlay at this level is very large. This level is dominated by indigenous companies and largely male driven. The second level is made up of independent marketers or semi-wholesalers who usually have distribution stores and hauling vehicles like the wholesalers. The third level consists of commissioned agents or Back up retail operators. They help to do bulk breaking by selling to the final retailers in small cartons. The fourth and last level is that of the final retailers. This is a female dominated sector and it has the largest number of operators in the distribution chain. This level can be characterized as being a perfectly competitive sector of the market. The initial capital requirement to operate here is small. This finding tends to support Ladipo(1988) who reported that four intermediaries are involved in the frozen fish distribution in Nigeria.

\subsection{Marketing Channels for Frozen Fish}

It is difficult to talk of a typical marketing channel for commodities in Nigeria. Although the channels for most commodities share many common features, there are also differences between commodities in terms of the number of exchange points between the producers and the consumers. Hence, the marketing margins for the different channels will differ depending on many factors like the distance from the central market, the level of infrastructural development in the markets, number of handlers and the nature or perish ability of the commodities.

One form of marketing channel identified in the frozen fish markets is based on refrigeration / freezing as a process of preservation. This is important because of the time and distances involved coupled with the tropical climate that could affect the quality of the commodities if not properly preserved. (See Figures 1 and 2).

Table 1 indicates that the average retail price for Mackerel is higher than that of Stockfish while that of Stockfish is greater than that of Sadinela. The same pattern is observed for the wholesale prices, marketing costs and net margins.

The percentages for the ratios MM-RP, MM-WP, NM-RP and NM-WP are low with a range of $4.3 \%$ to $12.6 \%$. Since the numerators are MM and NM while the denominators are RP and WP, the rate of returns of the 
numerators relative to the denominators translate into earnings per unit naira of RP and WP put into the marketing of frozen Fish in Bodija Market.

The percentages for the ratios MM-MC and NM-MC are very high with a range of $104.9 \%$ to $211.1 \%$ in Bodija Market. This implies that the MM and NM in frozen fish marketing are many times the MC.

Tables 2 and 3, display similar results to the ones in Table 1 so they are not discussed as reference can be made to Table 1 .

Table 4, shows the distribution of the retailers ' assessment of the problems of frozen fish marketing based on a 5-point Likert Scale and the six problems identified in this study. The problems are coded as extremely serious $=$ 5 , very serious $=4$, moderately serious $=3$, not serious $=2$ and no effect $=1$.

Table 5 contains the weighted scores and means of the problems assessed. The Likert scale values are used in conjunction with those in Table 4 to calculate the weighted scores and means. These values are ranked and then used to determine the severity of the marketing problems. The two measures indicate that power supply is the most severe problem followed by storage cost, spoilage, transport cost, finance and lastly market levies.

Table 6, presents the paired comparison preference scores of the problems as assessed by the retailers. The total choices row values are used to order the problems. Power supply has the highest total value of 335 . This is followed by storage (223), spoilage (186), transport cost (145, finance (121) and lastly market levies (108). The results here are the same as those obtained in Table 5.

Table 7, contains the MPs, Z-scores and the ratio scales. These three measures give the same rank ordering for the problems just like in Tables 5 and 6. This result is not surprising especially the case of power supply as the commodities require a high level of refrigeration. This is even so at the retail level where iced blocks are used for preservation of the commodities. An inadequacy in power supply could result in dire consequences for the market agents in terms of spoilage or deterioration in the quality and economic values of the commodities. The storage cost could be a serious problem if electricity is not available and the marketers have to provide this through self- generation of power. Over all, there is the need for improvement in the market environment in terms of the provision of infrastructures such as electricity and storage facilities.

\subsection{Conclusion and Recommendations}

The study revealed that the average retail price for Mackerel is higher than that of Stockfish while that of Stockfish is greater than that of Sadinela. The same pattern is observed for the wholesale prices, marketing and net margins. The percentages for the ratios MM-RP, MM-WP, NM-RP and NM-WP are low with a range of between $4.3 \%$ and $12.6 \%$ for Bodija Market, 9.9\% and 26.9\% in Oke- Ado and $2.4 \%$ and 9.4\% in Beere Market. These translate into earnings per unit naira of RP and WP put into the marketing of frozen Fish in the Markets. The percentages for the ratios MM-MC and NM-MC are very high with a range of $104.9 \%$ to $211.1 \%$ in Bodija Market, 158.55 to 271.35 in Oke-Ado and 61.65 to $181.7 \%$ in Beere. This implies that the MM and NM in frozen fish marketing are many times the MC. All the measures used to assess the problems gave the same rank ordering for them. Power supply is first. This is followed by storage, spoilage, transport cost, finance and lastly market levies. This result is not surprising especially the case of power supply as the commodities require a high level of refrigeration. This is even so at the retail level where iced blocks are used for preservation of the commodities. An inadequacy in power supply could result in dire consequences for the market agents in terms of spoilage or deterioration in the quality and economic values of the commodities. The storage cost could be a serious problem if electricity is not available and the marketers have to provide this through self- generation of power. Over all, there is the need for improvement in the market environment in terms of the provision of infrastructures such as electricity and storage facilities.

\section{References}

Adegeye, A.J. and Dittoh, J.S. (1985). Essentials of Agricultural Economics. Impact Publishers Nigeria Limited, Ibadan.

Adekanye, T.O. (1988). Readings in Agricultural Marketing. Longmans Nigeria Limited, 215 Pp.

Bock, R. Darrell; Jones, Lyle V. (1968). The measurement and prediction of judgment and choice.San Francisco, CA: Holden-Day, Inc. 370 p.

Brown, Thomas C.; Peterson, George L. (2009). An Enquiry Into the Method of Paired Comparison: Reliability, Scaling, and Thurstone's Law of Comparative Judgment United States Department of Agriculture Forest Service Rocky Mountain Research Station General Technical Report RMRS-GTR-216WWW January 2009. 
David, Herbert A. (1988). The method of paired comparisons (Second ed.). New York, NY: Oxford University Press. $188 \mathrm{p}$.

Dercon, S. (1995). On Market Integration and Liberalization: Method and Application to Ethiopia. Journal of Development Studies, 32(1): 112-143.

Godwin,S.K.. and Schroeder, T.C. (1991). Cointegration Tests and Spatial Price Linkages in Regional Cattle Markets. American Journal of Agricultural Economics, 73:452-464.

Guilford, J. P. (1954). Psychometric methods (Second ed.). New York: McGraw-Hill. 597 p.

Idachaba, F.S. (1991). The Nigerian Food Problem. Journal of Agriculture, Science and Technology, Vol. 1(1): 5- 16 June, 1991.

Jayaraj, D. (1992). Spatial Pricing in Groundnut Markets in Tamil Nadu. Indian Journal of Agricultural Economics, Vol. 47(1) Jan-March, 1992.

Ladipo, O.O. (1988). The Nigerian Frozen Fish Marketing System in Adekanye, T.O. Readings in Agricultural Marketing. Longmans Nigeria Limited. 215 Pp.

Nunnally, Jum C. (1976). Psychometric theory. New York: McGraw Hill. 640 p.

Olayemi, J.K. (1974). Food Marketing and Distribution in Nigeria: Problems and Prospects. Nigeria Institute of Social and Economic Research (NISER).

Palaskas, T.I.B; and Harris-White, B. (1993). Testing Market Integration: New Approaches with Case Material from West Bengal Food Economy. Journal of Development Studies, Vol. 3091): 1-5.

Rahji, M.A.Y; Popoola, L; and L.A. Adebisi. (2001). Analyses of the Demand for and Supply of Fish in Nigeria 1986-1997. Journal of West African Fisheries, Vol. 10: 543-550.

Silvapulle, P. and Jayasuriya, S. (1994). Testing for Phillipine`s Rice Market Integration : A Multiple Cointegration Approach. Journal of Agricultural Economics, 45(3):369-380.

Torgerson, Warren S. (1958). Theory and methods of scaling. New York, NY: John Wiley Sons.460P.

Zango-Daura, S. (2000). Fish Import Gulps N12 billion Yearly. New Nigerian Newspaper, Monday $22^{\text {nd }}$, May, 2000 Pg. 1.

Table 1. Results of the Market Margin Analysis at Bodija Market

\begin{tabular}{|l|l|l|l|}
\hline Parameter & $\begin{array}{l}\text { Mackerel } \\
\text { Naira/carton }\end{array}$ & $\begin{array}{l}\text { Sardinela } \\
\text { Naira /carton }\end{array}$ & $\begin{array}{l}\text { Stockfish } \\
\text { Naira/carton }\end{array}$ \\
\hline Average Retail Price(PR) & 2111.11 & 1500.00 & 1917.00 \\
\hline Ave Wholesale Price(WP) & 1938.00 & 1332.00 & 1662.50 \\
\hline Ave Marketing cost(MC) & 82.00 & 82.00 & 82.00 \\
\hline Market margin(MM) & 173.11 & 168.00 & 172.00 \\
\hline Net margin(NM) & 91.11 & 86.00 & 90.00 \\
\hline $\mathrm{MM} \mathrm{as \%} \mathrm{RP}$ & $8.2 \%$ & $11.2 \%$ & $9.0 \%$ \\
\hline $\mathrm{MM}$ as \% WP & $8.9 \%$ & $12.6 \%$ & $10.4 \%$ \\
\hline $\mathrm{MM} \mathrm{as} \mathrm{\%} \mathrm{MC}$ & $211.1 \%$ & $204.8 \%$ & $209.8 \%$ \\
\hline $\mathrm{NM} \mathrm{as \%} \mathrm{PR}$ & $4.3 \%$ & $5.7 \%$ & $4.7 \%$ \\
\hline $\mathrm{NM}$ as \% WP & $4.7 \%$ & $6.5 \%$ & $5.4 \%$ \\
\hline $\mathrm{NM}$ as \% MC & $111.1 \%$ & $104.9 \%$ & $109.8 \%$ \\
\hline
\end{tabular}

Source: Market Survey, 2008 
Table 2. Results of the Market Margin Analysis at Oke-Ado Market

\begin{tabular}{|l|l|l|l|}
\hline Parameter & $\begin{array}{l}\text { Mackerel } \\
\text { Naira/carton }\end{array}$ & $\begin{array}{l}\text { Sardinela } \\
\text { Naira /carton }\end{array}$ & $\begin{array}{l}\text { Stockfish } \\
\text { Naira /carton }\end{array}$ \\
\hline Average Retail Price(RP) & 2233.33 & 1571.00 & 2065.00 \\
\hline Ave Wholesale Price(WP) & 1883.33 & 1237.50 & 1726.00 \\
\hline Ave Marketing cost (MC) & 129.00 & 129.00 & 129.00 \\
\hline Market margin (MM) & 350.00 & 333.50 & 339.00 \\
\hline Net margin (NM) & 221.00 & 204.50 & 210.00 \\
\hline MM as \% RP & $15.8 \%$ & $21.2 \%$ & $16.4 \%$ \\
\hline MM as \% WP & $18.6 \%$ & $26.9 \%$ & $19.6 \%$ \\
\hline MM as \% MC & $271.3 \%$ & $258.5 \%$ & $262.8 \%$ \\
\hline NM as \% RP & $11.7 \%$ & $16.5 \%$ & $12.2 \%$ \\
\hline NM as \% WP & $9.9 \%$ & $13.0 \%$ & $10.2 \%$ \\
\hline NM as \% MC & $171.3 \%$ & $158.5 \%$ & $162.8 \%$ \\
\hline
\end{tabular}

Source: Market Survey, 2008

Table 3. Results of the Market Margin Analysis at Beere Market

\begin{tabular}{|l|l|l|l|}
\hline Parameter & $\begin{array}{l}\text { Mackerel } \\
\text { Naira/carton }\end{array}$ & $\begin{array}{l}\text { Sardinela } \\
\text { Naira/carton }\end{array}$ & $\begin{array}{l}\text { Stockfish } \\
\text { Naira /carton }\end{array}$ \\
\hline Average Retail Price(RP) & 2145.32 & 1550.00 & 2010.00 \\
\hline Ave Wholesale Price (WP) & 2005.56 & 1416.60 & 1885.76 \\
\hline Ave Marketing cost (MC) & 76.90 & 76.90 & 76.90 \\
\hline Marketing margin (MM) & 139.76 & 133.40 & 124.24 \\
\hline Net margin (NM) & 62.86 & 56.50 & 47.34 \\
\hline MM as \% RP & $6.5 \%$ & $8.6 \%$ & $6.2 \%$ \\
\hline MM as \% WP & $7.0 \%$ & $9.4 \%$ & $6.6 \%$ \\
\hline MM as \% MC & $181.7 \%$ & $173.5 \%$ & $161.6 \%$ \\
\hline NM as \% RP & $3.1 \%$ & $3.6 \%$ & $2.4 \%$ \\
\hline NM as \% WP & $2.9 \%$ & $4.0 \%$ & $2.5 \%$ \\
\hline NM as \% MC & $81.7 \%$ & $73.5 \%$ & $61.6 \%$ \\
\hline
\end{tabular}

Source: Market Survey, 2008

Table 4. Retailers`Assessment of Frozen Fish Marketing Problems

\begin{tabular}{|c|c|c|c|c|c|}
\hline Items/ Problems & $\begin{array}{c}\text { Extremely } \\
\text { serious } \\
(5)\end{array}$ & $\begin{array}{c}\text { Very } \\
\text { serious } \\
(4)\end{array}$ & $\begin{array}{c}\text { Moderately } \\
\text { serious } \\
(3)\end{array}$ & $\begin{array}{c}\text { Not } \\
\text { serious } \\
(2)\end{array}$ & No effect \\
\hline Spoilage & 11 & 11 & 17 & 11 & 40 \\
\hline Transport cost & 0 & 11 & 11 & 28 & 40 \\
\hline Finance & 0 & 7 & 23 & 17 & 43 \\
\hline Power supply & 49 & 11 & 7 & 0 & 23 \\
\hline Storage & 7 & 28 & 11 & 11 & 33 \\
\hline Market levies & 0 & 6 & 17 & 20 & 47 \\
\hline
\end{tabular}

Source: Market Survey, 2008 
Table 5. Weighted Scores and Means of the Assessed Marketing Problems

\begin{tabular}{|c|c|c|c|c|}
\hline Problems & $\begin{array}{c}\text { Weighted } \\
\text { Scores }\end{array}$ & $\%$ & $\begin{array}{c}\text { Weighted } \\
\text { Means }\end{array}$ & $\%$ \\
\hline Spoilage & 212 & 16.6 & 2.3556 & 16.6 \\
\hline Transport cost & 174 & 13.6 & 1.9333 & 13.6 \\
\hline Finance & 163 & 12.7 & 1.8111 & 12.7 \\
\hline Power supply & 333 & 26.0 & 3.7000 & 26.0 \\
\hline Storage & 235 & 18.4 & 2.6111 & 18.4 \\
\hline Market levies & 162 & 12.6 & 1.8000 & 12.6 \\
\hline Total & 1279 & 100.0 & 14.2111 & 100.0 \\
\hline
\end{tabular}

Source: Market Survey, 2008

Table 6. Paired Comparison Preference Scores of the Problems by the Retailers

\begin{tabular}{|c|c|c|c|c|c|c|}
\hline Problems & Spoilage & $\begin{array}{c}\text { Transport } \\
\text { cost }\end{array}$ & Finance & $\begin{array}{c}\text { Power } \\
\text { supply }\end{array}$ & Storage & $\begin{array}{c}\text { Market } \\
\text { levies }\end{array}$ \\
\hline Spoilage & - & 39 & 28 & 68 & 62 & 21 \\
\hline Transport cost & 51 & - & 39 & 76 & 68 & 17 \\
\hline Finance & 62 & 51 & - & 82 & 55 & 23 \\
\hline Power supply & 23 & 14 & 8 & - & 11 & 28 \\
\hline Storage & 28 & 23 & 31 & 79 & - & 19 \\
\hline Market levies & 22 & 18 & 15 & 30 & 27 & - \\
\hline Total Choices & 186 & 145 & 121 & 335 & 223 & 108 \\
\hline Rank Order & 3 rd & 4 th & 5 th & 1 st & 2 nd & 6 th \\
\hline
\end{tabular}

Source: Market Survey, 2008

Table 7. Estimated Values of Mean Proportions, Z-Scores and Ratio Scales

\begin{tabular}{|c|c|c|c|c|c|c|}
\hline Problems & MPs & Rank & Z-Scores & Rank & $\begin{array}{c}\text { Ratio } \\
\text { Scale }\end{array}$ & Rank \\
\hline Spoilage & 0.4278 & 3rd & -0.19 & 3rd & 0.39 & 3rd \\
\hline Transport cost & 0.3519 & 4 th & -0.38 & 4 th & 0.20 & 4th \\
\hline Finance & 0.3074 & 5 th & -0.50 & 5 th & 0.08 & 5th \\
\hline Power supply & 0.7037 & 1st & 0.54 & $1 \mathrm{st}$ & 1.12 & 1st \\
\hline Storage & 0.4963 & 2nd & -0.01 & 2nd & 0.57 & 2nd \\
\hline Market levies & 0.2833 & 6th & -0.58 & 6th & 0.00 & 6th \\
\hline
\end{tabular}

Source: Market Survey, 2008 

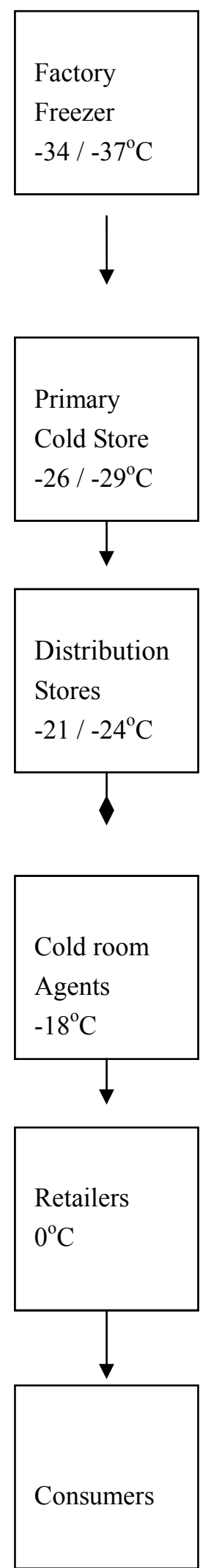

Figure 1. Illustrates this channel and the temperatures at each point of the distribution chain 


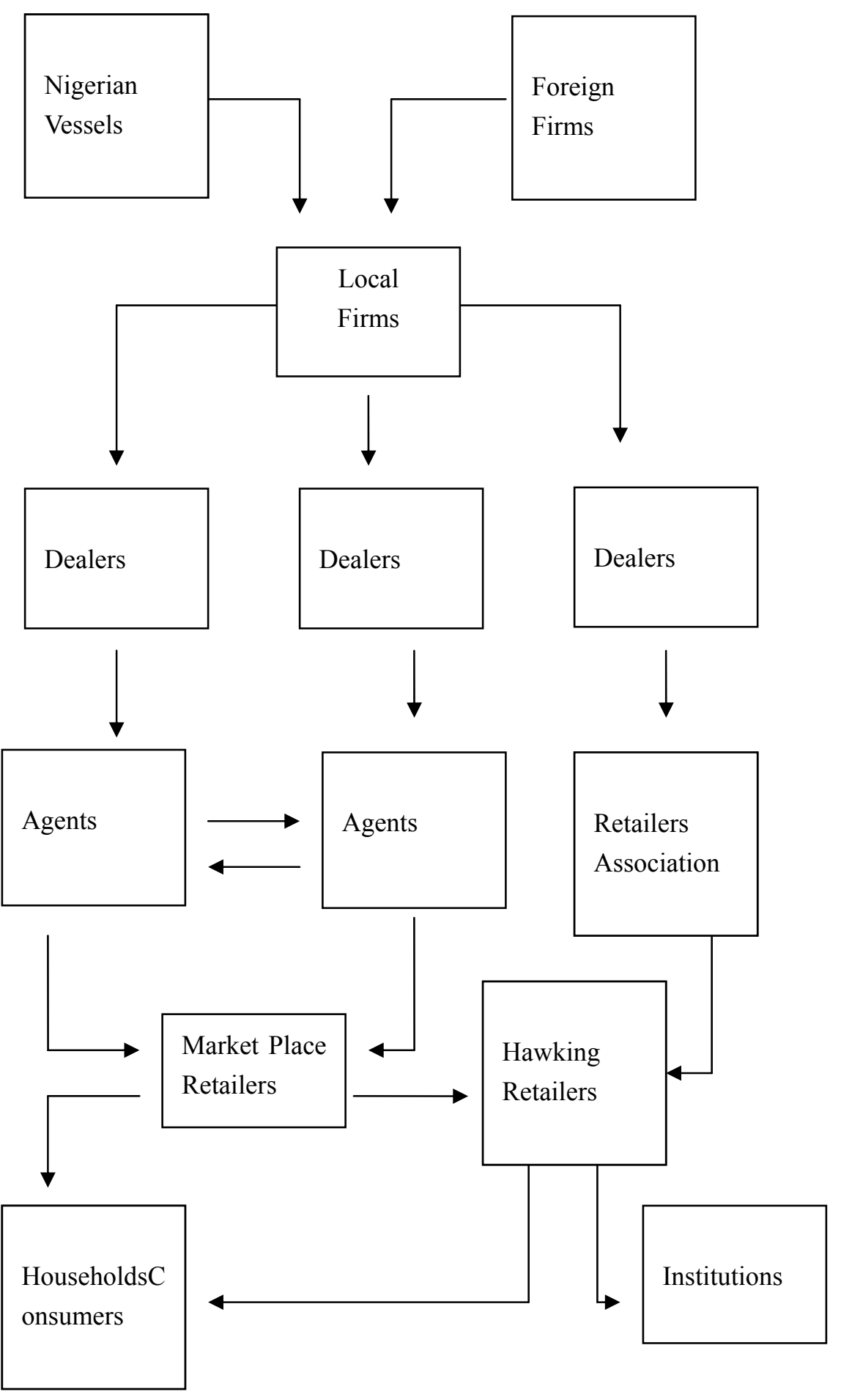

Figure 2. Presents another form of marketing channel based on the import and external trade linkages of frozen fish and all the market agents both foreign and local in the chain. In this way, the first objective is met 